\title{
An assessment of lung volumes and gas transfer in sickle-cell anaemia
}

\author{
G. J. M I LLER a nd G. R. SER JEA N T \\ Medical Research Council's Epidemiology Unit, and the Wellcome Sickle-Cell Anaemia Unit, \\ University of the West Indies, Kingston, Jamaica
}

Lung volumes, gas transfer, and anthropometry were assessed in sickle-cell anaemia in 13 patients with previous pulmonary episodes and 12 without this history. Respiratory symptoms were assessed with a standard questionnaire, total lung capacity and its subdivisions, the carbon monoxide transfer factor (TF), diffusion capacity of the alveolar capillary membrane (Dm), and the alveolar capillary blood volume (Vc) were measured, and stature, sitting height and chest diameters were recorded. Total lung capacity and vital capacity were reduced because the thorax was small relative to body size in these patients.

TF was reduced by anaemia, small lungs, and a low Dm which was not simply a consequence of small lungs. This reduction tended to be offset by an increase in Vc. The cause of the reduction in Dm above that due to small lungs was probably located in the pulmonary circulation. Anaemia was considered unlikely to be responsible, and although a difference between the reactivity of carbon monoxide with $\mathrm{Hb} \mathrm{A}$ and $\mathrm{Hb} \mathrm{S}$ may have contributed to the reduction in $\mathrm{Dm}$ and the increase in Vc, it was thought unlikely to be the only cause: Dm was significantly lower in patients with a history of pulmonary complications and in non-smokers than in those without this history and in smokers. Alveolar capillary collapse or occlusion may also have reduced Dm in sickle-cell anaemia and accounted for the greater reductions in those with previous pulmonary episodes and in non-smokers.

Patients with sickle-cell anaemia suffer from infective and infarctive lesions. Acute pulmonary episodes commonly occur but here the relative contributions of infection and ischaemia are difficult to assess (Diggs and Barreras, 1967). Petch and Serjeant (1970), in a clinical study, concluded that many episodes diagnosed as lobar pneumonia were associated with vascular obstruction either as the primary lesion or as a complication. A progressive form of pulmonary vascular obstruction with cor pulmonale has also been described (Moser and Shea, 1957).

Various pulmonary vascular disorders affect the single breath carbon monoxide transfer factor (TF) of the lung and its components, the diffusion capacity of the alveolar capillary membrane (Dm), and the volume of blood in the pulmonary capillary bed (Vc). McNeill, Rankin and Forster (1958) reported reductions in TF, Dm, and Vc in primary pulmonary hypertension, and Nadel, Gold, and Burgess (1968) noted a diminîshed TF and $\mathrm{Vc}$ in chronic pulmonary vascular obstruction prior to the onset of pulmonary hypertension. Other studies of gas transfer in pulmonary vascular disorders (McIlroy and Apthorp, 1958; Jones and Goodwin, 1965; Williams, Adler, and Colp, 1969) reported mild or moderate reductions in TF. Miller (1969) found that Dm was reduced in sickle-cell anaemia, and this has recently been confirmed by Femi-Pearse, Gazioglu, and Yu (1970). In this study an assessment has been made of lung volumes in sickle-cell anaemia and of TF, $\mathrm{Dm}$, and Vc to determine their value in the diagnosis of pulmonary vascular obstruction in this condition.

\section{PATIENTS AND METHODS}

Twenty-five adult patients (16 men and 9 women) were selected from a total of 317 persons attending the Sickle-Cell Anaemia Clinic of the University Hospital of the West Indies, Jamaica. The diagnosis of sicklecell anaemia wás based on the finding of only haemoglobins $S, F$, and $A_{2}$ on electrophoresis, normal $A_{2}$ values, characteristic red cell morphology, and family studies where possible. Patients with sickle thalassaemia and $\mathrm{Hb}$ SC disease were excluded. 
Six patients were selected because of repeated admissions for acute pulmonary episodes, and the remainder were studied irrespective of the clinical history. All were in a stable state at the time of study. Nine men were working full time and seven women were either housewives or in domestic employment. None of the nine remaining patients was unemployed because of physical disability. Six men smoked-but less than 10 cigarettes daily; 10 men and all women were non-smokers.

Each patient answered the revised form of the Medical Research Council's questionnaire on respiratory symptoms ${ }^{1}$ and the following were considered as acute pulmonary episodes: 1, a history of pneumonia or pleurisy; 2 , haemoptysis; 3 , isolated attacks of wheezing and breathlessness in a non-asthmatic subject; and 4, episodes of acute chest illness, with or without sputum production, that limited the patient's activities for a week (these were all accompanied by chest pain). Dyspnoea was graded according to the method of Fletcher (1952).

Stature and sitting height were measured with a stadiometer, subischial height was calculated from the difference, and lateral and anteroposterior chest diameters were measured with calipers. Weight was measured on a beam balance.

The forced expiratory volume in one second $\left(F E V_{1}\right)$ and forced vital capacity (FVC) were measured with a McDermott dry spirometer (Collins, McDermott, and McDermott, 1964). Vaiues for each patient were obtained $\mathrm{frcm}$ the mean of three technically satisfactory performances after two practice attempts. Total lung capacity (TLC), vital capacity (VC), functional residual capacity (FRC), and residual volume (RV) were measured with a spirometer by the closed circuit helium dilution method and all volumes were expressed in litres at body temperature and pressure saturated with water vapour (1, BTPS). The single breath carbon monoxide transfer factor (TF) was measured with an automatic apparatus (Meade et al., 1965) and Dm and Vc were obtained by the method of Roughton and Forster (1957) from measurements of TF at two levels of alveolar oxygen tension. As an index of distribution of ventilation the apparent volume of distribution of a single breath of helium taken up to TLC was expressed as a fraction of TLC measured by the closed circuit method. Haemoglobin concentration was measured on venous blood by the cyanmethaemoglobin method with a photoelectric colorimeter.

The pulmonary transfer factor, TF, is determined by the area and permeability of the alveolar capillary membrane and the amount and reactivity of haemoglobin in the alveolar capillaries. The relationships between these variables are described in the following equations :

Equation 1: $1 / \mathrm{TF}=1 / \mathrm{Dm}+1 / \theta \mathrm{Vc}$ (Roughton and Forster, 1957) where $\theta$ is the product of the rate at which carbon monoxide replaces oxygen in oxy-

1Obtainable from W. J. Holman, Ltd., Dawlish, Devon, England haemoglobin and the haemoglobin concentration. The reciprocal $1 / \theta$, is calculated from equation 2 .

$$
\frac{1 / \theta=a+b \mathrm{PcO}^{\circ} 2}{\frac{1-\mathrm{S}^{-} \mathrm{CO}}{100} \times \frac{\mathrm{Hb}}{i \frac{1 \cdot 6}{4}}} \text { (Coses, 1968) }
$$

where $\mathrm{S} \overline{\mathrm{c}} \mathrm{CO}$ is the mean saturation of haemoglobin with carbon monoxide (effectively zero, as all patients were requested not to smoke for 12 hours before the test), $\mathrm{Hb}$ is the haemoglobin concentration in $\mathrm{g} / 100$ $\mathrm{ml}, \mathrm{P} \quad \mathrm{O}_{2}$ is the mean tension of oxygen in plasma in the alveolar capillaries, and $a=0.34, b=0.0059$ for $\mathrm{Hb}$ A.

These relationships have been used to calculate a predicted transfer factor, $\mathbf{T F}^{\prime}$, for each patient when the haemoglobin concentration was normal $(14 \cdot 6 \mathrm{~g} /$ $100 \mathrm{ml}$ ) and the other variables in equations 1 and 2 were held constant, thus eliminating the effect of the anaemia on TF. Similarly, to eliminate both the effects of anaemia and a change in Vc on TF, a second predicted transfer factor $\left(\mathrm{TF}^{\prime \prime}\right)$ was calculated by inserting normal values for haemoglobin concentration and $\mathrm{Vc}$ in the equations while holding other variables constant. Changes in $\mathrm{TF}^{\prime \prime}$ were therefore due to changes in $\mathrm{Dm}$. TF and $\mathrm{TF}^{\prime \prime}$ were divided by TLC to express gas transfer per litre of lung volume, $\mathrm{K}$ and $\mathrm{K}^{\prime \prime}$, respectively.

In the statistical analysis males and females were treated separately. Predicted average normal values were derived from multilinear regression equations describing the lung function of healthy Jamaican adults of African ethnic origin (Miller, 1971). The significance of differences between the means of the measured and predicted values for the various indices of lung function were assessed by bivariate covariance analysis. Differences were considered significant if the likelihood of occurrence by chance alone was less than $5 \%(P<0.05)$.

\section{RESULTS}

ANTHROPOMETRY Table I presents the age, haemoglobin concentration, and anthropometry of the patients. The mean age of the male and

T A B L E I

AGE, ANTHROPOMETRY, AND HAEMOGLOBIN CONCENTRATION

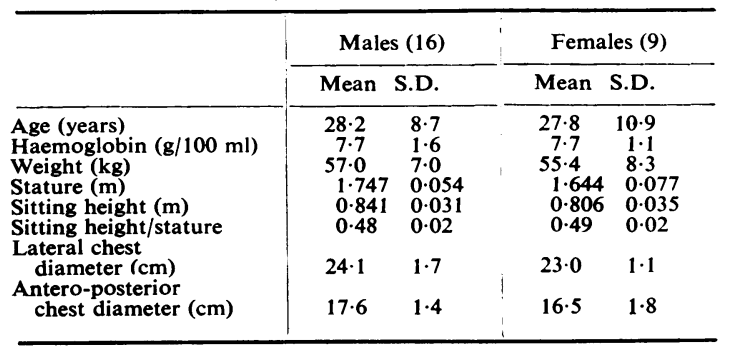


female patients was 28.2 years (S.D. 8.7) and 27.8 years (S.D. 10.9) respectively, and both groups had the same mean haemoglobin concentration $(7.7 \mathrm{~g} / 100 \mathrm{ml})$. The men were taller and heavier than the women, and in both sexes sitting height was less than subischial height, such that the ratio sitting height: stature was 0.48 (S.D. 0.02) for men and 0.49 (S.D. 0.02) for women. Lateral and anteroposterior chest diameters were larger in men than in women.

SYMPтоMS Eight men $(50.0 \%)$ and five women $(55.6 \%)$ gave a history of pulmonary episodes. Chest pain, pneumonia, haemoptysis, and wheezing attacks were mentioned in six, six, two, and two cases respectively. Five patients $(20 \%)$ had severe dyspnoea (grade IV), nine (36\%) were moderately dyspnoeic (grade III), and 3 (12\%) had minimal dyspnoea (grade II). Breathlessness was not significantly correlated with haemoglobin concentration $(r=0.34$ for men, 0.25 for women) or $\mathrm{Vc}(\mathrm{r}=0.29$ for men, 0.42 for women). With age and height held constant no significant relationship was found between the grade of dyspnoea and $\operatorname{Dm}(r=0.33$ and 0.30 for men and women respectively).

LUNG FUNCTION Table II shows that total lung capacity was reduced in both sexes because of a reduction in the vital capacity, the residual volume being normal. In men and women the mean TLC was $88 \%$ and $89 \%$ of the predicted normal value respectively, and the mean VC was $82 \%$ of the predicted normal value in both sexes. The small vital capacity produced similar reductions in the $F E V_{1}$ and FVC. The ratio of residual volume to total lung capacity (RV/TLC\%) was significantly increased, but the FEV \% and index of distribution of ventilation were normal in all patients and so excluded airways obstruction.

The transfer factor (TF) was significantly reduced in both men and womsn, the mean values of 21.8 and $16.7 \mathrm{ml} / \mathrm{min} / \mathrm{mmHg}$ being $65.9 \%$ and $71.1 \%$ of predicted normal values respectively. Similarly, $\mathbf{T F}^{\prime}$ and $\mathrm{TF}^{\prime \prime}$ were below normal in both sexes, the mean $\mathrm{TF}^{\prime}$ being 29.0 (88\% of normal) and $20.9(89 \%$ of normal) in men and women respectively. Mean Dm was $45 \cdot 7 \mathrm{ml} / \mathrm{min} /$

T A B L E I I

LUNG VOLUMES AND SUBDIVISIONS (1. BTPS)

\begin{tabular}{|c|c|c|c|c|c|c|c|c|c|c|}
\hline \multirow{3}{*}{ Index } & \multicolumn{5}{|c|}{ Males (16) } & \multicolumn{5}{|c|}{ Females (9) } \\
\hline & \multicolumn{2}{|c|}{ Observed } & \multicolumn{2}{|c|}{ Predicted $^{\mathbf{1}}$} & \multirow{2}{*}{$\mathbf{P}$} & \multicolumn{2}{|c|}{ Observed } & \multicolumn{2}{|c|}{ Predicted $^{1}$} & \multirow{2}{*}{$\mathbf{P}$} \\
\hline & Mean & S.D. & Mean & R.S.D. ${ }^{2}$ & & Mean & S.D. & Mean & R.S.D. ${ }^{2}$ & \\
\hline $\begin{array}{l}\text { TLC } \\
\text { VC } \\
\text { RV } \\
\text { RV/TLC (\%) } \\
\text { FRC } \\
\text { FEV } 1 \\
\text { FVC } \\
\text { FEV (\%) }\end{array}$ & $\begin{array}{r}4.9 \\
3.39 \\
1.59 \\
32.6 \\
2.74 \\
2.55 \\
3.13 \\
81.9\end{array}$ & $\begin{array}{l}0 \cdot 80 \\
0 \cdot 73 \\
0.41 \\
8 \cdot 0 \\
0.49 \\
0 \cdot 72 \\
0 \cdot 79 \\
6 \cdot 1\end{array}$ & $\begin{array}{r}5 \cdot 61 \\
4.15 \\
1.47 \\
26 \cdot 1 \\
3.27 \\
3.14 \\
3.80 \\
81 \cdot 7\end{array}$ & $\begin{array}{l}0.68 \\
0.50 \\
0.29 \\
3.3 \\
0.67 \\
0.49 \\
0.53 \\
8.7\end{array}$ & $\begin{array}{l}<0.001 \\
<0.001 \\
\text { N.S. } \\
<0.001 \\
<0.01 \\
<0.001 \\
<0.001 \\
\quad \text { N.S. }\end{array}$ & $\begin{array}{r}3.94 \\
2.44 \\
1.50 \\
37.5 \\
2.34 \\
2.10 \\
2.47 \\
84.2\end{array}$ & $\begin{array}{l}0.50 \\
0.24 \\
0.42 \\
6.6 \\
0.52 \\
0.52 \\
0.47 \\
6.2\end{array}$ & $\begin{array}{r}4 \cdot 42 \\
2.96 \\
1.30 \\
31 \cdot 5 \\
2 \cdot 64 \\
2.37 \\
2 \cdot 88 \\
81 \cdot 5\end{array}$ & $\begin{array}{l}0.46 \\
0.44 \\
0.24 \\
5.4 \\
0.49 \\
0.41 \\
0.47 \\
7.6\end{array}$ & $\begin{aligned} &< 0.01 \\
&< 0.001 \\
& \text { N.S. } 0.01 \\
&<0.01 \\
& \text { N.S. } \\
& \text { N.S. } \\
&<0.05 \\
& \text { N.S. }\end{aligned}$ \\
\hline
\end{tabular}

1 Multilinear regression equations describing the lung volumes of the controls on stature and age (Miller, 1970) were used to derive predicted normal values. Twice sitting height has been substituted for stature to correct for anthropometric disproportion.

2 R.S.D. is the residual standard deviation about the multilinear regression.

N.S. $=$ not significant.

T A B L E I I I

TRANSFER FACTOR AND SUBDIVISIONS

\begin{tabular}{|c|c|c|c|c|c|c|c|c|c|c|}
\hline \multirow{3}{*}{ Index } & \multicolumn{4}{|c|}{ Males (16) } & & \multicolumn{5}{|c|}{ Females (9) } \\
\hline & \multicolumn{2}{|c|}{ Observed } & \multicolumn{2}{|c|}{ Predicted } & \multirow{2}{*}{$\mathbf{P}$} & \multicolumn{2}{|c|}{ Observed } & \multicolumn{2}{|c|}{ Predicted } & \multirow{2}{*}{$\mathbf{P}$} \\
\hline & Mean & S.D. & Mean & R.S.D. & & Mean & S.D. & Mean & R.S.D. & \\
\hline $\begin{array}{l}\text { TF }(\mathrm{ml} / \mathrm{min} / \mathrm{mmHg}) \\
\mathrm{TF}^{\prime}(\mathrm{ml} / \mathrm{min} / \mathrm{mmHg}) \\
\mathrm{Dm}(\mathrm{ml} / \mathrm{min} / \mathrm{mmHg})\end{array}$ & $\begin{array}{l}21 \cdot 8 \\
29 \cdot 0 \\
45 \cdot 7\end{array}$ & $\begin{array}{r}4 \cdot 1 \\
5 \cdot 9 \\
16 \cdot 4\end{array}$ & $\begin{array}{l}33 \cdot 1 \\
33 \cdot 1 \\
63 \cdot 0\end{array}$ & $\begin{array}{r}3 \cdot 7 \\
3.7 \\
9 \cdot 5 \\
\text { S.D. }\end{array}$ & $\begin{array}{l}<0.001 \\
\sim 0.01 \\
<0.001\end{array}$ & $\begin{array}{l}16 \cdot 7 \\
20 \cdot 9 \\
29 \cdot 0\end{array}$ & $\begin{array}{l}2 \cdot 6 \\
4 \cdot 1 \\
7 \cdot 9\end{array}$ & $\begin{array}{l}23 \cdot 5 \\
23 \cdot 5 \\
44 \cdot 7\end{array}$ & $\begin{array}{l}2 \cdot 1 \\
2 \cdot 1 \\
6 \cdot 2 \\
\text { S.D. }\end{array}$ & $\begin{array}{l}<0.001 \\
<0.05 \\
<0.001\end{array}$ \\
\hline $\begin{array}{l}\mathrm{Vc}(\mathrm{ml})^{1} \\
\mathrm{~K}^{\prime \prime}(\mathrm{ml} / \mathrm{min} / \mathrm{mmHg} / \mathrm{l} .)\end{array}$ & $\begin{array}{l}89 \cdot 6 \\
5 \cdot 53\end{array}$ & $\begin{array}{r}19 \cdot 3 \\
1 \cdot 1\end{array}$ & $\begin{array}{c}69 \cdot 5 \\
6 \cdot 43\end{array}$ & $\begin{array}{l}3.0 \\
26.0 \\
0.62\end{array}$ & $\begin{array}{l}<0.01 \\
<0.01\end{array}$ & $\begin{array}{c}78 \cdot 0 \\
5 \cdot 20\end{array}$ & $\begin{array}{r}18 \cdot 3 \\
1 \cdot 0\end{array}$ & $\begin{array}{r}61 \cdot 0 \\
6 \cdot 14\end{array}$ & $\begin{array}{l}23 \cdot 5 \\
0.50\end{array}$ & $\begin{array}{l}<0.05 \\
<0.001\end{array}$ \\
\hline
\end{tabular}

Predicted values were derived as in Table II.

i Control values for Vc are given as the mean values and S.D. for 33 male and 33 female Jamaican subjects. 
$\mathrm{mmHg}(72.5 \%$ of normal) in men and $29.0 \mathrm{ml} /$ $\mathrm{min} / \mathrm{mmHg}(64.9 \%$ of normal) in women, and Vc was increased to approximately $130 \%$ of normal values in both sexes. These data are presented in Table III.

Tables IV, V, and VI show that VC was reduced in both sexes irrespective of a history of pulmonary complication or smoking. In men the reductions in Dm and $\mathrm{K}^{\prime \prime}$ were significant in the group with pulmonary episodes and in the group of non-smokers but not in the group without this history or the group of smokers. One of six male smokers gave a history of pulmonary complications, compared with 7 of 10 non-smokers $(P=0.08)$. In women $\mathrm{Dm}$ and $\mathrm{K}^{\prime \prime}$ were reduced irrespective of a history of pulmonary episodes. $\mathrm{Vc}$ and the degree of breathlessness were unaffected by pulmonary episodes or smoking.

\section{DISCUSSION}

This study has confirmed that the lung function and anthropometry of patients with sickle-cell anaemia differ from that of healthy subjects of African ethnic origin. Long limbs in sickle-cell anaemia reduce the ratio sitting height:standing height below the normal range of $0.50-0.51$ for healthy subjects of the same ethnic origin (Ashcroft, Beadnell, Miller, and Bell, 1969). The thorax is not only short relative to body stature

T A B L E I V

LUNG FUNCTION IN MEN WITH AND WITHOUT ACUTE PULMONARY EPISODES

\begin{tabular}{|c|c|c|c|c|c|c|c|c|c|c|}
\hline \multirow{3}{*}{ Index } & \multicolumn{5}{|c|}{ With Acute Episodes (8) } & \multicolumn{5}{|c|}{ Without Acute Episodes (8) } \\
\hline & \multicolumn{2}{|c|}{ Observed } & \multicolumn{2}{|c|}{ Predicted } & \multirow{2}{*}{$\mathbf{P}$} & \multicolumn{2}{|c|}{ Observed } & \multicolumn{2}{|c|}{ Predicted } & \multirow{2}{*}{$\mathbf{P}$} \\
\hline & Mean & S.D. & Mean & R.S.D. & & Mean & S.D. & Mean & R.S.D. & \\
\hline $\begin{array}{l}\text { VC }(1 . \text { BTPS }) \\
\text { Dm }(\mathrm{ml} / \mathrm{min} / \mathrm{mmHg}) \\
\mathrm{K}^{\prime \prime}(\mathrm{ml} / \mathrm{min} / \mathrm{mmHg} / 1 .) \\
\text { Vc }(\mathrm{ml}) \\
\text { Grade of dyspnoea }\end{array}$ & $\begin{array}{c}2 \cdot 96 \\
36 \cdot 8 \\
5 \cdot 2 \\
97 \cdot 5 \\
2 \cdot 63\end{array}$ & $\begin{array}{c}0 \cdot 57 \\
14 \cdot 0 \\
1 \cdot 1 \\
18 \cdot 4 \\
1 \cdot 19\end{array}$ & $\begin{array}{c}4.06 \\
60.9 \\
6 \cdot 7\end{array}$ & $\begin{array}{l}0.50 \\
9.5 \\
0.6\end{array}$ & $\begin{array}{l}<0.001 \\
<0.001 \\
<0.001\end{array}$ & $\begin{array}{c}3 \cdot 82 \\
55 \cdot 2 \\
5 \cdot 8 \\
81 \cdot 8 \\
2 \cdot 13\end{array}$ & $\begin{array}{c}0 \cdot 62 \\
13 \cdot 0 \\
1 \cdot 0 \\
17 \cdot 8 \\
0.99\end{array}$ & $\begin{array}{c}4 \cdot 25 \\
65 \cdot 1 \\
6 \cdot 2\end{array}$ & $\begin{array}{l}0.50 \\
9.5 \\
0.6\end{array}$ & $\begin{array}{l}<0.05 \\
\text { N.S. } \\
\text { N.S. } \\
\text { N.S. } \\
\text { N.S. }\end{array}$ \\
\hline
\end{tabular}

Predicted values were derived as in Table II.

T A B L E V

LUNG FUNCTION IN WOMEN WITH AND WITHOUT ACUTE PULMONARY EPISODES

\begin{tabular}{|c|c|c|c|c|c|c|c|c|c|c|}
\hline \multirow{3}{*}{ Index } & \multicolumn{5}{|c|}{ With Acute Episodes (5) } & \multicolumn{4}{|c|}{ Without Acute Episodes (4) } & \multirow{3}{*}{$\mathbf{P}$} \\
\hline & \multicolumn{2}{|c|}{ Observed } & \multicolumn{2}{|c|}{ Predicted } & \multirow{2}{*}{$\mathbf{P}$} & \multicolumn{2}{|c|}{ Observed } & \multicolumn{2}{|c|}{ Predicted } & \\
\hline & Mean & S.D. & Mean & R.S.D. & & Mean & S.D. & Mean & R.S.D. & \\
\hline $\begin{array}{l}\text { VC (1. BTPS }) \\
\text { Dm }(\mathrm{ml} / \mathrm{min} / \mathrm{mmHg}) \\
\mathrm{K}^{\prime \prime}(\mathrm{ml} / \mathrm{min} / \mathrm{mmHg} / \mathrm{l} .) \\
\text { VC }(\mathrm{ml}) \\
\text { Grade of dyspnoea }\end{array}$ & $\begin{array}{c}2 \cdot 41 \\
28 \cdot 6 \\
5 \cdot 15 \\
81 \cdot 0 \\
2 \cdot 00\end{array}$ & $\begin{array}{c}0 \cdot 31 \\
6 \cdot 8 \\
1 \cdot 22 \\
18 \cdot 8 \\
1 \cdot 00\end{array}$ & $\begin{array}{c}3.04 \\
44.7 \\
6.12\end{array}$ & $\begin{array}{l}0 \cdot 44 \\
6 \cdot 2 \\
0 \cdot 50\end{array}$ & $\begin{array}{l}<0.001 \\
<0.001 \\
<0.05\end{array}$ & $\begin{array}{c}2 \cdot 48 \\
29 \cdot 4 \\
5 \cdot 25 \\
74 \cdot 3 \\
3 \cdot 25\end{array}$ & $\begin{array}{c}0 \cdot 15 \\
10 \cdot 3 \\
0 \cdot 84 \\
19 \cdot 7 \\
1 \cdot 50\end{array}$ & $\begin{array}{c}2 \cdot 86 \\
44 \cdot 6 \\
6 \cdot 16\end{array}$ & $\begin{array}{l}0 \cdot 44 \\
6 \cdot 2 \\
0 \cdot 50\end{array}$ & $\begin{aligned} & \text { N.S. } \\
&< 0.001 \\
&< 0.001 \\
& \text { N.S. } \\
& \text { N.S. }\end{aligned}$ \\
\hline
\end{tabular}

Predicted values were derived as in Table II.

T A B L E V I

LUNG FUNCTION IN MALE SMOKERS AND NON-SMOKERS

\begin{tabular}{|c|c|c|c|c|c|c|c|c|c|c|}
\hline \multirow{3}{*}{ Index } & \multicolumn{4}{|c|}{ Smokers (6) } & & \multicolumn{5}{|c|}{ Non-smokers (10) } \\
\hline & \multicolumn{2}{|c|}{ Observed } & \multicolumn{2}{|c|}{ Predicted } & \multirow{2}{*}{$\mathbf{P}$} & \multicolumn{2}{|c|}{ Observed } & \multicolumn{2}{|c|}{ Predicted } & \multirow{2}{*}{$\mathbf{P}$} \\
\hline & Mean & S.D. & Mean & R.S.D. & & Mean & S.D. & Mean & R.S.D. & \\
\hline $\begin{array}{l}\text { VC(l. BTPS }) \\
\left.\mathrm{Dm}^{\prime \prime} \mathrm{ml} / \mathrm{min} / \mathrm{mmHg}\right) \\
\mathrm{K}^{\prime \prime}(\mathrm{ml} / \mathrm{min} / \mathrm{mmHg} / 1 .) \\
\text { Vc }(\mathrm{ml}) \\
\text { Grade of dyspnoea }\end{array}$ & $\begin{array}{c}3 \cdot 73 \\
54 \cdot 2 \\
5 \cdot 38 \\
88 \cdot 2 \\
2 \cdot 3\end{array}$ & $\begin{array}{l}0 \cdot 80 \\
14 \cdot 3 \\
1 \cdot 00 \\
22 \cdot 4 \\
1 \cdot 2\end{array}$ & $\begin{array}{c}4 \cdot 21 \\
62 \cdot 4 \\
5 \cdot 86\end{array}$ & $\begin{array}{l}0.50 \\
9 \cdot 5 \\
0.62\end{array}$ & $\begin{array}{c}<0.05 \\
\text { N.S. } \\
\text { N.S. }\end{array}$ & $\begin{array}{c}3 \cdot 18 \\
41 \cdot 0 \\
5 \cdot 62 \\
90 \cdot 5 \\
2 \cdot 4\end{array}$ & $\begin{array}{c}0 \cdot 64 \\
15 \cdot 7 \\
1 \cdot 12 \\
18 \cdot 4 \\
1 \cdot 1\end{array}$ & $\begin{array}{c}4 \cdot 12 \\
63 \cdot 3 \\
6 \cdot 78\end{array}$ & $\begin{array}{l}0.50 \\
9 \cdot 5 \\
0.62\end{array}$ & $\begin{aligned}<0.001 \\
<0.001 \\
<0.01 \\
\text { N.S. } \\
\text { N.S. }\end{aligned}$ \\
\hline
\end{tabular}

Predicted values were derived as in Table II. 
in this disease, but the lateral chest diameter is also narrower than that of healthy subjects of the same ethnic type (Ashcroft and Serjeant, 1971). These anthropometric differences will reduce the volume of the thorax and lungs relative to body stature, and also reduce TF and Dm, which are a function of lung volume.

The use of multilinear regression equations incorporating coefficients on anthropometric indices such as body stature to predict 'normal values' will be valid only if there is consistency in the anthropometry of the group being studied and the group whose lung function is described by these equations. This requirement is not met when comparing sickle-cell anaemia patients with healthy African subjects, and therefore the regression equations used to predict normal values for lung volumes TF and $\mathrm{Dm}$ in this study are to some extent inappropriate. Regression equations containing a regression coefficient on sitting height would be more appropriate but are not available. Previous studies of lung volumes in sickle-cell anaemia (Fowler, Smith, and Greenfield, 1957 ; Sproule, Halden, and Miller, 1958 ; Bromberg and Jensen, 1967 ; Femi-Pearse et al., 1970) not only failed to allow for the anthropometric differences between healthy Africans and those with sickle-cell anaemia, but also neglected the difference in anthropometry between Caucasians and Africans by employing regression equations describing the lung function of Caucasians.

In this study allowance has been made for the long limbs in sickle-cell anaemia by substituting twice sitting height for stature in the calculations of normal values, but, despite this, lung volumes TF, Dm, and TF", which is a function of Dm, remain significantly reduced as shown in Tables II and III, due at least in part to an inability to allow for narrow chest diameters.

If the difference between the observed and predicted values for Dm and TF" was due simply to the narrower chest diameters of sickle-cell patients than of healthy Africans, then $\mathrm{K}^{\prime \prime}$ (TF" per unit volume of the lung) would be normal, which was not the case in this study (Table III). The significant reduction in $\mathrm{K}^{\prime \prime}$ suggests that $\mathrm{Dm}$ is also reduced by some factor other than small lungs, and in the absence of any ventilatory defect this is likely to be located in the pulmonary circulation.

The results show that patients with a history of acute pulmonary episodes have a lower Dm than those without this history, and also suggest a relationship between smoking, acute pulmonary episodes, and lung function. In men, non-smokers appear to have a greater tendency than smokers to pulmonary complications and a reduction in Dm above that due to small lungs. This finding is interesting but requires cautious interpretation. Sirs (1963) reported that carbon monoxide reduced sickle-cell formation in vitro and in vivo in one patient, but Purugganan and McElfresh (1964) could not confirm this. While it is theoretically possible that carbonmonoxyhaemoglobin $\mathrm{S}$ formation could be protective, it might be that smokers are self selected. For example, perhaps only those patients with satisfactory lung function find smoking pleasurable. Although there were no exsmokers among the non-smokers, some might have tried smoking on occasions. The numbers of male smokers and non-smokers are also small and a large series would be more reliable.

Jouasset-Strieder, Cahill, Byrne, and Gaensler (1965) showed that Dm was reduced but Vc remained normal when dogs were made anaemic by replacing whole blood with plasma and they concluded, as did Burrows and Niden (1963), that gas was transferred principally where alveolar and red cell membranes made direct contact. However, Rankin, McNeill, and Forster (1961) were unable to demonstrate any significant improvement in Dm after transfusion of anaemic patients. A similar reduction in $\mathrm{Dm}$ to that in sickle-cell anaemia occurs in haemoglobin SC disease, in which the anaemia is mild (Femi-Pearse et al., 1970). In this study no relationship was found between the degree of anaemia and the reduction in Dm. Thus the effect of anaemia on Dm remains unclear and, furthermore, it seems untenable to argue that a reduction in the alveolar capillary red cell volume is responsible for the low Dm of sickle-cell anaemia because the large volume of blood in these capillaries will compensate for a low haematocrit and maintain alveolar capillary red cell volume and the area of contact between alveolar capillary and red cell membrane. A study of the change in Dm and Vc after transfusion in sickle-cell anaemia may clarify this point.

The value of $\theta$ for $\mathrm{Hb}$ A was derived from in vitro studies by Forster, Roughton, Kreuzer, and Briscoe (1957), but the method is laborious and has not been performed for $\mathrm{Hb} \mathrm{S}$, so that the assumption made in this study and by FemiPearse et al. (1970), that $\theta \mathrm{Hb} \mathrm{S}$ is equal to $\theta \mathrm{Hb} \mathrm{A}$, may not be justified. Smaller values than 0.0059 for constant ' $b$ ' in equation 2 will reduce Vc and increase $\mathrm{Dm}$, and therefore these indices could have been miscalculated because the value of 00059 for ' $b$ ' has underestimated the true reactivity of carbon monoxide with $\mathrm{Hb} \mathrm{S}$. Inappropriate values of the constant term ' $a$ ' in equation 2 will affect $\mathrm{Dm}$ only, which will increase as ' $a$ ' 
T A B L E V I I

MEAN Dm AND Vc IN MEN WITH SICKLE-CELL ANAEMIA, ASSUMING THAT CONSTANT 'b' IN EQUATION $2=0$.0041

\begin{tabular}{|c|c|c|c|c|c|c|c|c|c|}
\hline \multirow{3}{*}{ Group } & \multirow{3}{*}{ No. } & \multicolumn{4}{|c|}{$\mathrm{Dm}(\mathrm{ml} / \mathrm{min} / \mathrm{mmHg})$} & \multirow{3}{*}{$\mathbf{P}$} & \multirow{2}{*}{\multicolumn{2}{|c|}{$\begin{array}{l}\text { Observed Vc }(\mathrm{ml}) \\
\text { (normal value } 69 \cdot 5 ; \\
\text { S.D. 26.0) }\end{array}$}} & \multirow{3}{*}{$\mathbf{P}$} \\
\hline & & \multicolumn{2}{|c|}{ Observed } & \multicolumn{2}{|c|}{ Predicted } & & & & \\
\hline & & Mean & S.D. & Mean & R.S.D. & & Mean & S.D. & \\
\hline $\begin{array}{l}\text { With pulmonary episodes } \\
\text { Without pulmonary episodes } \\
\text { Non-smokers } \\
\text { Smokers }\end{array}$ & $\begin{array}{r}8 \\
8 \\
10 \\
6\end{array}$ & $\begin{array}{l}43 \cdot 1 \\
72 \cdot 4 \\
49 \cdot 2 \\
71 \cdot 9\end{array}$ & $\begin{array}{l}19 \cdot 2 \\
24 \cdot 5 \\
22 \cdot 8 \\
26 \cdot 9\end{array}$ & $\begin{array}{l}60 \cdot 9 \\
65 \cdot 1 \\
63 \cdot 3 \\
62 \cdot 4\end{array}$ & $\begin{array}{l}9 \cdot 5 \\
9 \cdot 5 \\
9 \cdot 5 \\
9 \cdot 5\end{array}$ & $\begin{array}{r}<0.05 \\
\text { N.S. } \\
<0.05 \\
\text { N.S. }\end{array}$ & $\begin{array}{l}68 \cdot 3 \\
58 \cdot 1 \\
63 \cdot 5 \\
62 \cdot 7\end{array}$ & $\begin{array}{l}17 \cdot 5 \\
12 \cdot 6 \\
16 \cdot 4 \\
15 \cdot 8\end{array}$ & $\begin{array}{l}\text { N.S. } \\
\text { N.S. } \\
\text { N.S. } \\
\text { N.S. }\end{array}$ \\
\hline
\end{tabular}

Predicted values were derived as in Table II.

increases. A variable proportion (up to $25 \%$ ) of red cells in sickle-cell anaemia have undergone a permanent membrane change and are irreversibly sickled (Jensen, 1969) and it is conceivable that $\theta$ differs between these cells and the non-irreversibly sickled cells.

What contribution any difference between the reactivity of carbon monoxide with $\mathrm{Hb} \mathrm{A}$ and $\mathrm{Hb} \mathrm{S}$ has made to the changes in Dm and $\mathrm{Vc}$ in sickle-cell anaemia cannot be decided at present, but the following theoretical exercise is of some interest in this respect. Let us assume that the observed values for $\mathrm{Vc}$ in sickle-cell anaemia have been overestimated by $30 \%$ because the true value for ' $b$ ' in equation 2 is less than 0.0059 for $\mathrm{Hb} \mathrm{S}$, then ' $b$ ' for $\mathrm{Hb} \mathrm{S}$ will be about $0.0041(0.0059 \times$ $0 \cdot 7)$.

Table VII presents the mean Dm and Vc for men with and without a history of acute pulmonary episodes and male smokers and nonsmokers, assuming that ' $b$ ' is equal to 0.0041 . Men without acute pulmonary episodes are now estimated to have a mean Dm of $72.4 \mathrm{ml} / \mathrm{min} / \mathrm{mmHg}$ compared with a predicted mean of $65.1 \mathrm{ml} / \mathrm{min} /$ $\mathrm{mmHg}$, and the respective figures for male smokers are 71.9 and $62.4 \mathrm{ml} / \mathrm{min} / \mathrm{mmHg}$, differences which are still not statistically significant. Men with pulmonary episodes are estimated to have a mean $\mathrm{Dm}$ of $43.1 \mathrm{ml} / \mathrm{min} / \mathrm{mmHg}$ compared with a predicted mean of $60.9 \mathrm{ml} / \mathrm{min} /$ $\mathrm{mmHg}$ and the respective figures for male nonsmokers are 49.2 and $63.3 \mathrm{ml} / \mathrm{min} / \mathrm{mmHg}$, differences which remain statistically significant. $\mathrm{Vc}$ is similar to that of healthy African men in all groups.

The reduction in $\mathrm{Dm}$ in those who have a history of pulmonary complications and do not smoke is unlikely to be due to the true value of ' $a$ ' in equation 2 being larger than 0.34 , for in this case Dm for those without pulmonary complications and for smokers will be significantly greater than predicted normal values. Therefore, a difference between $\theta \mathrm{Hb} \mathrm{S}$ and $\theta \mathrm{Hb}$ A could account for the raised $\mathrm{Vc}$ in sickle-cell anaemia and for the reductions in Dm observed in men who smoke and who have no history of pulmonary complications, but it seems unlikely to account completely for the reductions in $\mathrm{Dm}$ observed in those who do not smoke and have no history of acute pulmonary episodes. Now if we assume that the increased $\mathrm{Vc}$ in sickle-cell anaemia is real and that 0.0059 approximates to the true value of ' $b$ ' for $\mathrm{Hb} S$, then changes in the constant ' $a$ ' would not affect the significance of differences in Dm between these groups of men, which remain to be explained.

Pulmonary haemodynamic changes are well recognized in sickle-cell anaemia and both an increased venous admixture effect and increased anatomical shunting of mixed venous blood through the lungs have been reported (Fowler et al., 1957 ; Sproule et al., 1958 ; Bromberg and Jensen, 1967). Alveolar capillary occlusion or collapse in the presence of an increased resting cardiac output (Leight, Snider, Clifford, and Hellems, 1954) will reduce Dm by decreasing the area of pulmonary blood-to-gas interface. Any further dilatation of the surviving capillary bed to accommodate the diverted blood flow will probably restore $\mathrm{Dm}$ less than $\mathrm{Vc}$ for whereas the change in area of alveolar capillary membrane available for gas transfer is a function of the radius of the capillary, the change in capillary blood volume is a function of the square of the radius. The net effect of these alterations is likely to be a reduction in Dm, and they might explain the differences in gas transfer between those with and without a history of acute pulmonary episodes, and between smokers and non-smokers.

Diffuse pulmonary fibrosis and pulmonary interstitial oedema can both produce a reduction in $\mathrm{Dm}$ due to ventilation-perfusion imbalance (Finley, Swenson, and Comroe, 1962) but neither of these conditions is a recognized occurrence in sickle-cell anaemia.

The capacity for exercise in sickle-cell anaemia will be limited not only by abnormalities of the musculoskeletal system caused by bone infarctions 
and infection but also by defects in oxygen transport. In the cardiovascular system the main defect is anaemia, which tends to be offset by an increased cardiac output (Leight et al., 1954) and a raised total blood volume (Erlandson, Schulman, and Smith, 1960). In the respiratory system defects include a reduced vital capacity and maximum breathing capacity, and possibly a reduction in $\mathrm{Dm}$ for oxygen. The limiting factor in exercise will vary from patient to patient but is possibly located in the respiratory system in some. A study of the responses to progressive exercise would be informative in this respect.

\section{REFERENCES}

Ashcroft, M. T., Beadnell, H. M. S. G., Miller, G. J., and Bell, R. (1969). Anthropometric measurements of Guyanese adults of African and East Indian racial groups. Trop. geogr. Med., 21, 169.

_ and Serjeant, G. R. (1971). Body habitus of Jamaican adults with sickle cell anaemia. To be published.

Bromberg, P. A., and Jensen, W. N. (1967). Arterial oxygen unsaturation in sickle cell disease. Amer. Rev. resp. Dis., 96, 400 .

Burrows, B., and Niden, A. H. (1963). Effects of anemia and hemorrhagic shock on pulmonary diffusion in the dog lung. J. appl. Physiol., 18, 123.

Collins, M. M., McDermott, M., and McDermott, T. J. (1964). Bellows spirometer and transistor timer for the measurement of forced expiratory volume and vital capacity. J. Physiol. (Lond.), 172, 39P.

Cotes, J. E. (1968). Lung Function, 2nd ed., p. 255. Blackwell, Oxford.

Diggs, L. W., and Barreras, L. (1967). Pulmonary emboli versus pneumonia in patients with sickle cell anemia. Memphis mid-S. med. J., 42, 375.

Erlandson, M. E., Schulman, I., and Smith, C. H. (1960). Studies on congenital hemolytic syndromes, III. Rates of destruction and production of erythrocytes in sickle cell anemia. Pediatrics, 25, 629.

Femi-Pearse, D., Gazioglu, K. M., and Yu, P. N. (1970). Pulmonary function studies in sickle cell disease. J. appl. Physiol., 28, 574.

Finley, T. N., Swenson, E. W., and Comroe, J. H. (1962). The cause of arterial hypoxemia at rest in patients with "alveolarcapillary block syndrome". J. clin. Invest., 41, 618.

Fletcher, C. M. (1952). The clinical diagnosis of pulmonary emphysema-an experimental study. Proc. roy. Soc. Med., 45, 577.

Forster, R. E., Roughton, F. J. W., Kreuzer, F., and Briscoe, W. A. (1957). Photocolorimetric determination of rate of uptake of $\mathrm{CO}$ and $\mathrm{O}_{2}$ by reduced human red cell suspensions at $37^{\circ}$ C. J. appl. Physiol., 11, 260.
Fowler, N. O., Smith, O., and Greenfield, J. C. (1957). Arterial blood oxygenation in sickle cell anemia. Amer. J. med. Sci., 234, 449.

Jensen, W. N. (1969). Fragmentation and the "freakish poikilocyte". Amer. J. med. Sci., 257, 355.

Jones, N. L., and Goodwin, J. F. (1965). Respiratory function in pulmonary thromboembolic disorders. Brit. med. J., $1,1089$.

Jouasset-Strieder, D., Cahill, J. M., Byrne, J. J., and Gaensler, E. A. (1965). Pulmonary diffusing capacity and capillary blood volume in normal and anemic dogs. J. appl. Physiol., 20, 113.

Leight, L., Snider, T. H., Clifford, G. O., and Hellems, H. K. (1954). Hemodynamic studies in sickle cell anemia. Circulation, 10, 653.

Mcllroy, M. B., and Apthorp, G. H. (1958). Pulmonary function in pulmonary hypertension. Brit. Heart J., 20, 397.

McNeill, R. S., Rankin, J., and Forster, R. E. (1958). The diffusing capacity of the pulmonary membrane and the pulmonary capillary blood volume in cardiopulmonary disease. Clin. Sci., 17, 465.

Meade, F., Saunders, M. J., Hyett, F., Reynolds, J. A., Pearl, N., and Cotes, J. E. (1965). Automatic measurement of lung function. Lancet, 2, 573.

Miller, G. J. (1969). A study of lung function in sickle cell anemia. (Abstract: From the First International Sickle Cell Anemia Conference.) Blood, 34, 731.

(1971). Lung volumes and indices of gas transfer in healthy Jamaican adults of African ethnic origin. In preparation.

Moser, K. M., and Shea, J. G. (1957). The relationship between pulmonary infarction, cor pulmonale and the sickle states. Amer. J. Med., 22, 561.

Nadel, J. A., Gold, W. M., and Burgess, J. H. (1968). Early diagnosis of pulmonary vascular obstruction. Value of pulmonary function tests. Amer.J. Med., 44, 16.

Petch, M. C., and Serjeant, G. R. (1970). Clinical features of pulmonary lesions in sickle-cell anaemia. Brit. med. J., 3, 31 .

Purugganan, H. B., and McElfresh, A. E. (1964). Failure of carbonmonoxy sickle-cell hæmoglobin to alter the sickle state. Lancet, 1, 79.

Rankin, J., McNeill, R. S., and Forster, R. E. (1961). The effect of anemia on the alveolar-capillary exchange of carbon monoxide in man. J. clin. Invest., 40, 1323.

Roughton, F. J. W., and Forster, R. E. (1957). Relative importance of diffusion and chemical reaction rates in determining rate of exchange of gases in the human lung. J. appl. Physiol., 11, 290.

Sirs, J. A. (1963). The use of carbon monoxide to prevent sickle-cell formation. Lancet, 1, 971.

Sproule, B. J., Halden, E. R., and Miller, W. F. (1958). A study of cardiopulmonary alterations in patients with sickle cell disease and its variants. J. clin. Invest., 37, 486.

Williams, M. H., Adler, J. J., and Colp, C. (1969). Pulmonary function studies as an aid in the differential diagnosis of pulmonary hypertension. Amer. J. Med., 47, 378. 